\title{
Cytokines in inflammatory bowel disease
}

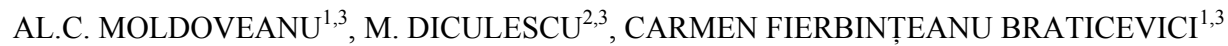 \\ ${ }^{1}$ Internal Medicine II and Gastroenterology Clinic, University Hospital Bucharest \\ ${ }^{2}$ Department of Gastroenterology, Fundeni Clinical Institute, Bucharest \\ 3“Carol Davila" University of Medicine and Pharmacy, Bucharest
}

\begin{abstract}
Inflammatory bowel diseases are chronic afflictions, characterized by active and remission periods. Inflammation is the most common type of response that the human body uses as a defense mechanism against aggressors from the environment. The frequency and degree of inflammation depends on the size of the affected tissues. The gastrointestinal tract is, by far, the most susceptible tissue to inflammatory responses, because of its constant exposure to various antigenic, mutagenic and toxic factors.

In inflammatory bowel diseases there is a loss of immune tolerance to intestinal flora that is mediated by various substances, including cytokines.Cytokines represent a key signal in the intestinal immune response. Activated dendritic cells and macrophages secrete cytokines that actively intervene in inflammation regulation, in both Crohn's disease and ulcerative colitis. After their secretion by antigen presented cells, cytokines activate and differentiate $\mathrm{T}$ cells, stirring up the adaptive immune response.

Cytokines have an important role in the pathogenesis of inflammatory bowel diseases. The identification of new cytokines, as well as the changing of the pathogenesis paradigms in inflammatory bowel diseases has been done on animal tests and clinical studies. Thus, there is promising evidence basis for future therapy research based on cytokines, and anti-cytokine antibodies.
\end{abstract}

Keywords: inflammatory bowel disease, immune response, cytokines.

Inflammatory bowel diseases (IBD) are chronic afflictions, characterized by active and remission periods. The IBD entity includes three forms of disease: Crohn's Disease (CD), Ulcerative Colitis (UC) and Indeterminate Colitis. As of this moment, the pathogenesis of this group of diseases is not fully understood.

Inflammation is the most common type of response that the human body uses as a defense mechanism against aggressors from the environment. The frequency and degree of inflammation depends on the size of the affected tissues. The gastrointestinal tract is, by far, the most susceptible tissue to inflammatory responses, because of its constant exposure to various antigenic, mutagenic and toxic factors. Even in normal conditions, the intestinal mucosa is in a state of "physiologic inflammation", manifested by the abundance of leukocytes in the intraepithelial and subepithelial compartments [1][2]. This is the consequence of an immune response to bacterial antigens and antigens in food. This concept has led to the idea that the bowel represents the largest lymphoid organ in the human body [1][3].

There is, also, a real inflammatory response (what could be called "pathological inflammation"), dominated by cells of the immune system from the intestinal mucosa. According to this theory, the active immune cells, represented by the neutrophils, macrophages and cytotoxic T-cells act as aggressors that attack and destroy the cells in the vicinity, either by direct contact or indirectly by releasing soluble factors like reactive oxygen species or nitric metabolites, cytotoxic proteins, lytic enzymes or cytokines [1][4][5].

There are two response models for the nonimmune cells of the intestinal mucosa:

1. A unidirectional model, where all nonimmune cells of the mucosa are passive, waiting to be damaged and eventually die as a result of the actions of effector immune cells [1] (Fig. 1).

\section{A bidirectional or multidirectional model,} where all the cell types that populate the mucosa have an active role in the intestinal immunity and inflammation. Epithelial, endothelial, mesenchymal, nervous cells have effector and regulatory roles, including immune-like functions. Even cellular components appear to play an important active role in the immuno-regulation activity of the extracellular matrix, in normal conditions as well as in 
the presence of inflammation [1][6][7]. The multidirectional model of interference between effector cells and target cells is probably the most realistic and can best explain the mechanism of chronic inflammation of the bowel in IBDs [1] (Figure 2). Thus, the reactive behavior of non-immune cells can be explained. This causes symptoms and clinical modifications like pain, changes in intestinal motility, fibrous structures, fistulas, intestinal occlusion or neoplastic transformation.

In IBDs there is a loss of immune tolerance to intestinal flora that is mediated by various substances, including cytokines.
Cytokines represent a key signal in the intestinal immune response. Cytokines are small peptides produced by immune cells that have the role of transmitting intercellular signals, the stimulation of cell proliferation for the antigen specific effector cells and the autocrine, paracrine and endocrine mediation of local and systemic inflammation. Activated dendritic cells and macrophages secrete cytokines that actively intervene in inflammation regulation, in both $\mathrm{CD}$ and UC. After their secretion by antigen presented cells (APCs), cytokines activate and differentiate $\mathrm{T}$ cells, activating the adaptive immune response.

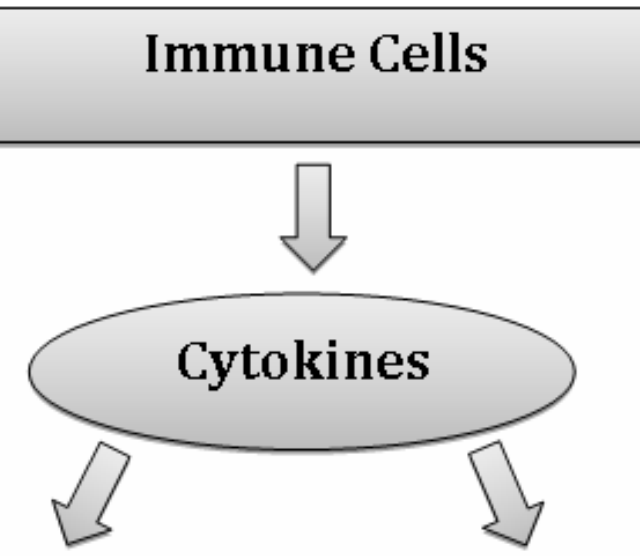

Non-Immune Cells

\section{Extracellular Matrix}

Fig. 1. Unidirectional model of cell-cell interactions in intestinal inflammation.

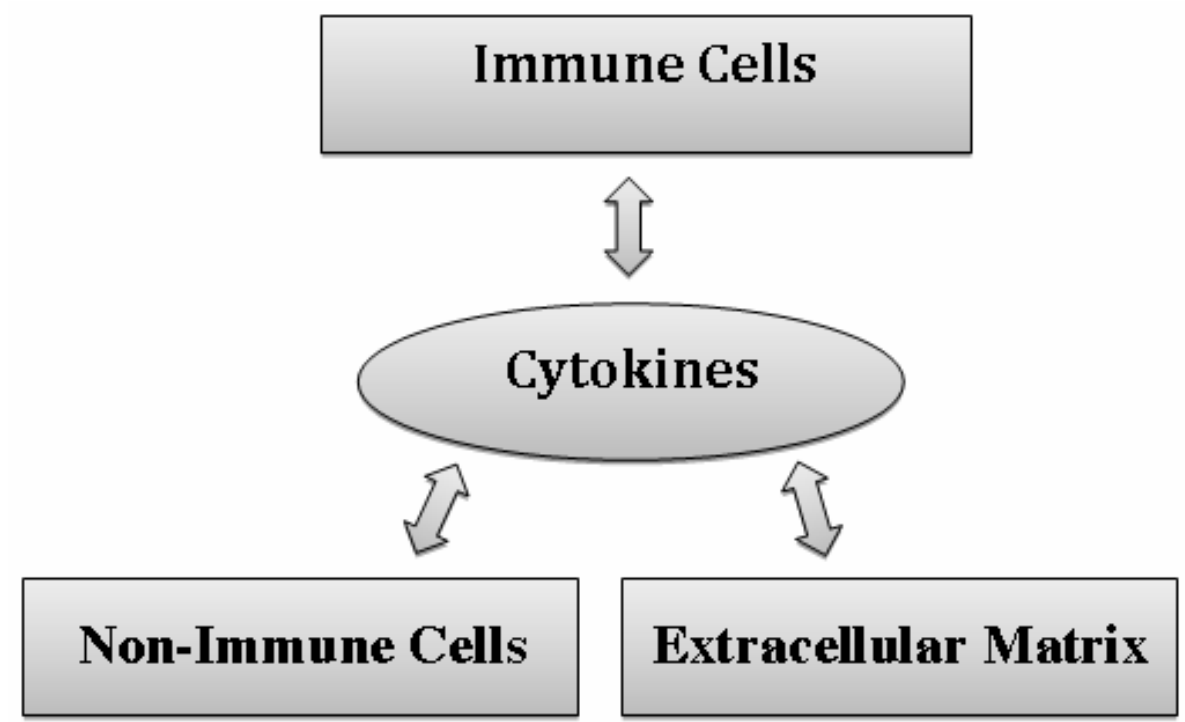

Fig. 2. The bidirectional or multidirectional model. 
$\mathrm{T}$ helper cells $(\mathrm{Th})$ can be differentiated in either Th1 or Th2 cells that can produce various types of cytokines. In IBDs, the elimination of over-activated and auto-reactive $\mathrm{T}$ cells is perturbed and a disequilibrium of activated Treg/Th1, Th2 and Th17 cells occurs. The lack of regulation by $\mathrm{T}$ cells or an overproduction of effector $\mathrm{T}$ cells participates in the development and exacerbation of IBDs [8][9].

Together, APCs, Th1, Th2, regulatory T cells and Th17 (recently discovered) and cytokines produced by them have a complex role in the development of IBDs [9][10]. The pathway by which the activation of cytokines influences the immune response in IBDs can be very different from one form of the disease to another [9] [11].

Cellular interactions can be modulated by the action of traditional cytokines like Tumor Necrosis Factor $\alpha$ (TNF- $\alpha)$, Gamma Interferon (INF- $\gamma$ ), Interleukins (IL-1, IL-6, IL-4, IL-5, IL-10), Transforming Growth Factor $\beta$ (TGF- $\beta$ ) - or of other, more recently described cytokines like IL-13, IL-12, IL-18, IL-23, that can have a pro-inflammatory effect as well as an anti-inflammatory effect [9].

It appears that $\mathrm{CD}$ is mediated by the Th1/ Th17 cytokines and characterized by the increase in production of INF- $\gamma$ and TNF- $\alpha$ (Figure 3). IL-12 and IL-23 control the differentiation of Th1 cells that, together with IL-15, IL-18 and IL-21, produce a stabilization of Th1 cells.

UC is characterized by the production of IL-13 by the natural killer T (NKT) CD1 cells, and by the production of cytokines by Th2 cells [9]. It appears that $\mathrm{UC}$ is a disease mediated by Th2 cytokines and is characterized by an increase in production of IL-5 and a normal production of INF- $\gamma$ [12-14]. In contrast, the production of IL-4 by Th2 cells was not increased in UC, which leads to the conclusion that it is a "Th-2 like" disease, rather than a true Th2 disease. NKT cells that produce IL-13 and IL-5 are the effectors of the main response [14] (Figure 4).

\section{PRO-INFLAMMATORY CYTOKINES}

\section{TUMOR NECROSIS FACTOR $\alpha$}

Lymphocytes and APCs are responsible for the inflammation in IBDs, especially by increasing the production of the Tumor Necrosis Factor $\alpha$ $(\mathrm{TNF}-\alpha)$.

TNF- $\alpha$ is produced by macrophages, monocytes and differentiated $\mathrm{T}$ cells. It has a proinflammatory effect through an increased production of IL- $1 \beta$ and IL- 6 , the expression of adhesion molecules, the proliferation of fibroblasts and procoagulant factors and the initiation of the acute response, cytotoxic and apoptotic phases, but also the inhibition of apoptosis [15][16]. The expression of TNF- $\alpha$ has been identified in the colonic tissues and macrophages in both CD and UC [17]. The serum levels of TNF- $\alpha$ correlates with the presence of clinical and biological elements that indicate the activity of the intestinal disease [18]. Clinical studies have shown an important improvement in patients with $\mathrm{CD}$, after the administration of antiTNF- $\alpha$ therapy, like infliximab, adalimumab or certolizumab pergola [19].
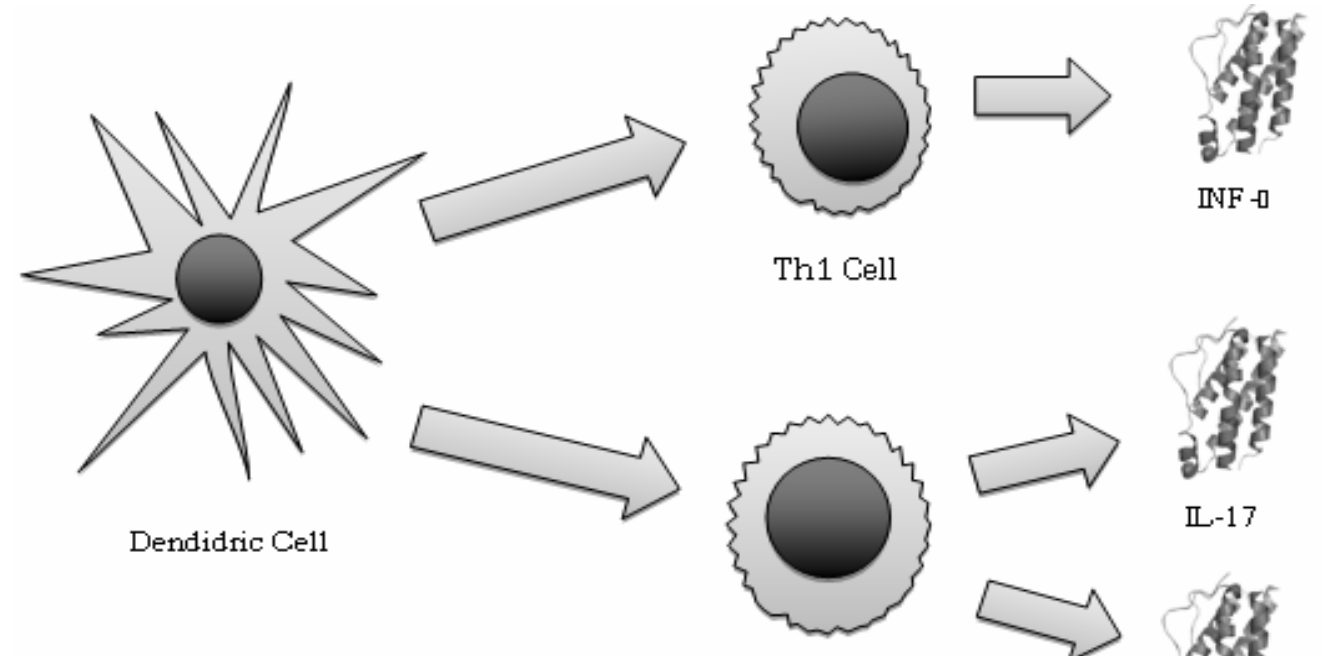

Th17 Ce11
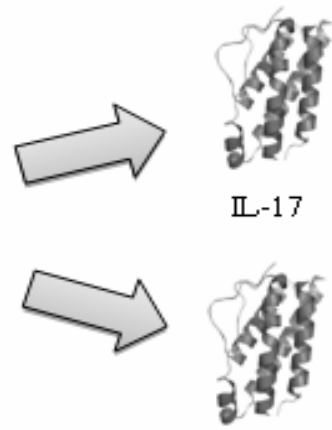

IL-22

Fig. 3. Th1/Th17 Response in Crohn's Disease. 


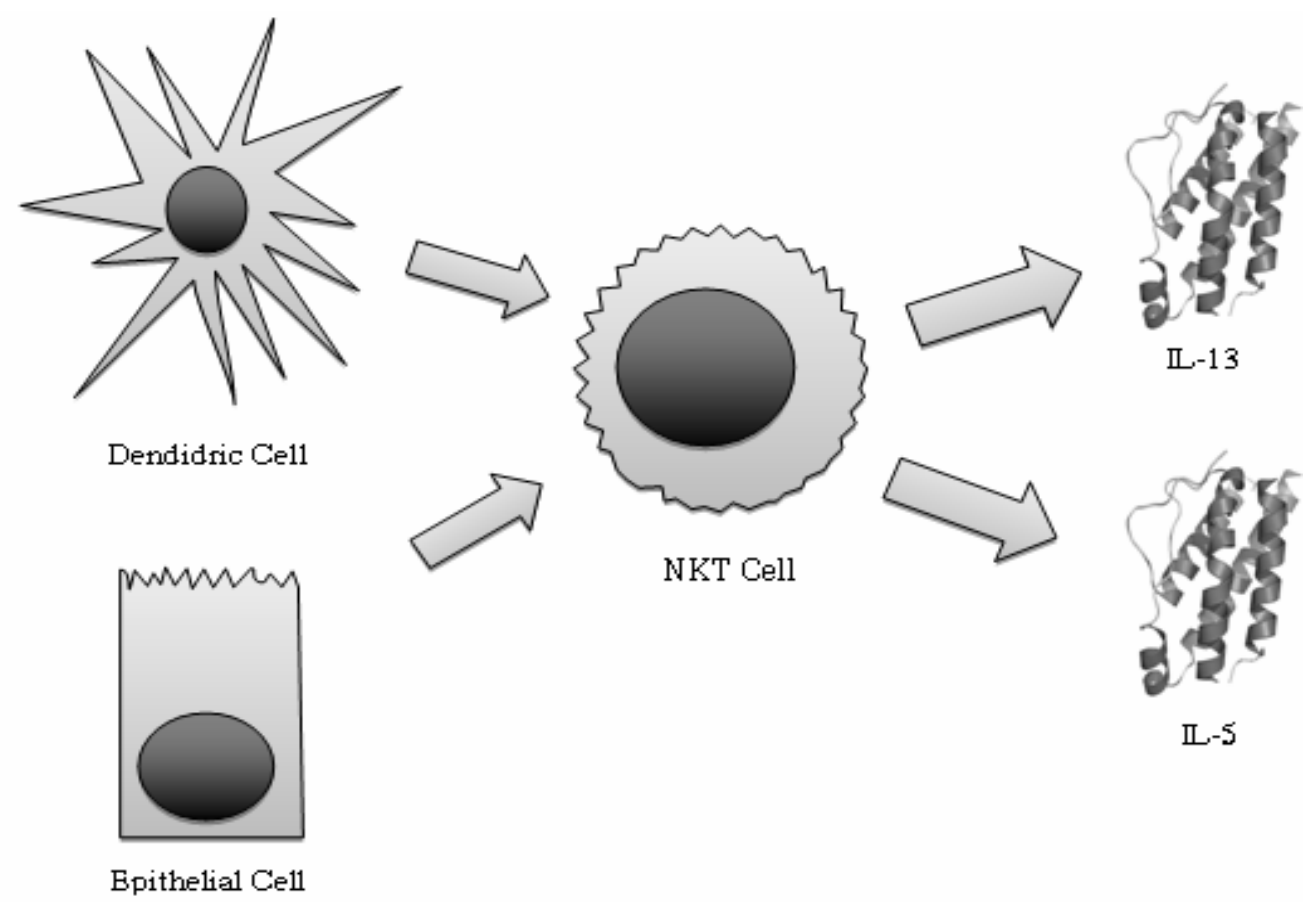

Fig. 4. Th2-Like Response in Ulcerative Colitis.

The signaling pathway of TNF- $\alpha$ uses two serum soluble receptors, TNF receptor type I and II (STNF-RI, STNF-RII). The levels of these receptors correlate well with disease activity in IBD patients. More precisely, sTNF-RI up-regulates in the serum of IBD patients, compared to the healthy controls, and could potentially be used as a marker for disease activity [20]. The levels of sTNF-RII are significantly higher in patients with $\mathrm{CD}$ compared to patients with UC and could be used as an extra parameter for the differentiation between the two diseases [9][19].

However, the activation of the STNF-RI based immune response was recently shown on animal models to reduce the mortality associated with intestinal lesions [21].

\section{TNF-LIKE LIGAND 1A}

TNF-like 1A (TL1A) is a cytokine, whose participation to intestinal inflammation has been relatively recently demonstrated. It is secreted by APCs, T cells as well as endothelial cells. Their signaling pathway involves binding of the Death Domain-Containing Receptor 3(DR3).

TL1A appears to stimulate the secretion of INF- $\gamma$ through the stimulation of Th1 cells. A larger percentage of lymphocytes express the DR3 receptor for TL1A, in biopsies taken from afflicted bowel areas in $\mathrm{CD}$ and UC patients, and an increased synthesis of INF- $\gamma$ has correlated with disease severity in IBD patients [22].
The studies performed on mice suggest that TL1A is a co-stimulating cytokine that optimizes the Th1 and Th17 responses, inducing inflamemation [14]. Its pro-inflammatory effect affects both Th1/Th17 and Th2 cells. This dichotomy augments both types of $\mathrm{T}$ cell response. Studies performed on animals regarding TL1A are consistent with what is found in IBDs. Increased levels of TL1A have been shown in both CD and UC [22-25]. CD14+ macrophages in CD produce large quantities of TL1A, which will determine an increase in INF- $\gamma$ and IL-17.

It appears that TL1A produces an augmentation of the inflammatory effect more than the induction of an inflammatory effect as its primary mechanism. The polymorphism of TL1A genes is associated with an increased risk for CD [26].

\section{INTERLEUKIN 1}

Interleukin 1 (IL-1) along with TNF- $\alpha$ is important in the pathogenesis of IBD due to its upregulatory and pro-inflammatory activity. The IL-1 system is formed mainly by IL- $1 \alpha$ and IL- $1 \beta$, both of which induce the production of type 2 cyclooxygenase, phospholipase $\mathrm{A}$ and inducible nitric oxide synthase (iNOS) [27]. The tissular level of IL-1 was found to be significantly increased in UC patients compared to control [28].

The IL-1 system also includes antagonists of the IL-1 receptors (IL-1Ra), as a control mechanism. In UC, IL-1, IL-1Ra and the Transforming Growth 
factor $\beta 1$ (TGF $\beta 1)$ influence the size and time length of the inflammatory process. The IL-1Ra/ IL-1 ratio has frequently been used as a predictor of inflammation of the mucosa, however the level of IL-1, rather than the level of IL-1Ra or the ratio IL-1Ra/IL-1 correlates best with the degree of severity of inflammation [28].

IL-1Ra inhibits IL-1 only in severely inflamed tissues of IBD patients while TGF $\beta 1$ 's controlling effect on inflammation has been more obvious in mild cases of UC [28].

\section{INTERLEUKIN 6}

Interleukin 6 (IL-6) performs its pro-inflammatory action by means of the IL- 6 soluble receptor (sIL-6R). The combination of the soluble receptor IL-6 (sIL-6R) and IL-6 plays an important role in the multiple immunological reactions that appear in IBD and the levels of IL-6 and of sIL-6R can correlate with multiple clinical manifestations that appears in CD and UC, including fibrogenesis [9, 29-32].The peripheral immune cells, colonic epithelial cells and cells from the lamina propria along with an active form of the IL-6/STAT3 system could be responsible for the strong correlation with the degree of mucosa inflammation [33].

STAT-3 induces anti-apoptotic factors like Bcl-2 and Bcl-xL, resulting in increased $\mathrm{T}$ cell resistance to apoptosis. This cycle of $\mathrm{T}$ cell accumulation, mediated by the resistance to apoptosis finally leads to chronic inflammation [34]. Blocking the IL-6 signaling pathway leads to the apoptosis of T cells, which shows that the IL- 6 - sIL-6R system mediates the resistance of $\mathrm{T}$ cells to apoptosis in CD [32, 34]. Anti sIL-6R antibodies have been shown to reduce the levels of INF- $\gamma$, TNF- $\alpha$ and IL-1 $\beta$ mRNA and have suppressed the expression of several intercellular adhesion molecules in the colonic vascular endothelium [35][36]. The IL-6/ STAT3 signaling in the activation of $\mathrm{T}$ mucosal cells has been suggested as a therapeutic target for the future [37].

\section{INTERLEUKIN 18}

Interleukin 18 (IL-18) is produced by intestinal epithelial cells and has been initially identified as an IFN- $\gamma$ producing factor. It has several similarities with the IL-1 family, including structure, action, receptor, signal transmission model and antiinflammatory action [38].

The equilibrium between IL-18 and its natural inhibitor, Interleukin 18 Binding Protein
(IL-18BP), can have a role in IBD pathogenesis [39]. An increase in the local production of IL-18 and IL18-BP has been shown in chronic lesions compared to control in CD [40], but the increase in IL18-BP is insufficient to control inflammation [39].

The IL-12 cytokine can act synergic with IL-18 to promote the production of INF- $\gamma$, causing severe inflammation of the intestine [41]. The development of Th1 CD4+ cells in the intestinal mucosa is induced by IL-12 produced by activated macrophages and IL-18 produced by activated macrophages and colonic epithelial cells. The synergic effect is caused by up-regulation mechanism of the receptor for IL-18 by IL-12 [42].

IL-18 may play a key role in Th1 mediated disorders, including $\mathrm{CD}$, and thus, there could be a rationale for an anti-IL-18 based therapy [40].

\section{INTERLEUKIN 17}

Recently, a new type of $\mathrm{T}$ helper cell has been identified, called "Th17" and it is characterized by the production of Interleukin 17(IL-17) and has been identified as having an important role in inflammatory response [43]. Five other members of the IL-17 family have been identified, named IL-17B to IL-17F. IL-17A is exclusively produced in Th17 cells [44].

IL-17 favorizes the production of multiple pro-inflammatory factors, including TNF- $\alpha$, IL-6 and IL-1 $\beta$, which has led to the conclusion that IL-17 has a very important role in the amplification and localization of inflammation [45-47], as well as the process of fibrosis in CD [48][49]. TNF- $\alpha$ and IL-6, both of which are produced by Th17 cells, not only sustain the development of Th17 cells, but also have a synergic action with IL-17 to increase the production of pro-inflammatory mediators [45].

IL-17 as well as Th17 cells have been identified as having an increased serum and intestinal tissue level in IBD patients [50]. IL-17 has not been identified in the tissues of inactive patients or other types of colitis [51].

\section{INTERLEUKIN 12 AND INTERLEUKIN 23}

Interleukin 12 (IL-12) and Interleukin 23 (IL-23) belong to the IL-12 family of cytokines. They are produced mainly by activated APCs and other cells like dendritic cells and phagocytes [52]. IL-12 induces the production of INF- $\gamma$ and the differentiation of Th0 cells into Th1 cells. It represents a link between innate resistance and adaptive resistance. 


\section{ANTI-INFLAMMATORY AND IMMUNOMODULATOR CYTOKINES}

\section{INTERLEUKIN 4}

Interleukin 4 (IL-4) induces the differentiation of naive T helper cells (Th0 cells) to Th2 cells. A study on animal models has shown that treatment with anti IL-4 antibodies leads to increased INF- $\gamma$ production and to the induction of a shift of Th2 cells to the Th1 type [53].

Another study has shown that the administration of IL-4 determines a significant reduction in the increase of Vascular Endothelial Growth Factor (VEGF) that normally appears in the peripheral blood in CD and UC patients, suggesting that a defective immunosuppressive effect of IL-4 may contribute to the pathologic mechanism of IBD [54].

\section{INTERLEUKIN 10}

Interleukin 10 (IL-10) is a cytokine with antiinflammatory effects that inhibits both the antigen presentation and the subsequent release of proinflammatory cytokines. An inactivation of IL-10 in mice has led to the increased production of IL12 and INF- $\gamma$ [55][56]. In CD with active inflamemation and granulomas, the IL-10 levels were found to be decreased.

Regulatory B cell subtype (Bregs cells) participate in the production of IL-10, and thus contribute to the anti-inflammatory effect and have a protective role [57]. It has been shown on animal models that transferring Breg cells in IL-10 deficient mice blocked the development of colitis [58].

\section{TRANSFORMATION GROWTH FACTOR $\beta$}

TGF- $\beta$ as an inhibitor cytokine acts as a regulatory key for the inflammatory response. The decrease in TGF- $\beta$ activity is considered responsible for the development of several autoimmune disorders, including IBDs [59]. Some evidence suggests that TGF- $\beta$ acts by protecting the host tissues from the luminal aggressions and facilitates the repair of the mucosal lesions in IBD [60][61].

\section{OTHER CYTOKINES WITH ROLES IN IBDS}

Other cytokines, like IL-21 and IL-22, can play a role in the induction of IBDs as well as in other autoimmune diseases.

\section{INTERLEUKIN 21}

Interleukin 21 (IL-21) acts on the intestinal epithelium, maintaining the inflammation induced by Th1 by induction of INF- $\gamma$ production [62][63]. It has been demonstrated that IL-21 increases the number of NK cells on a large scale [64]. IL-21 is expressed by $\mathrm{T}$ cells, $\mathrm{B}$ cells and non-immune cells, like fibroblasts. IL-21 contributes to the differentiation of Th17 cells [65], with an over expression in both CD and UC [50]. The highest levels were identified in CD [66]. IL-21 also induces IL-22 synthesis in CD4+ T cells [67].

\section{INTERLEUKIN 22}

Interleukin 22 (IL-22) acts on subepithelial myofibroblasts and increases the production of proinflammatory cytokines and matrix-degrading molecules [68]. IL-22 has a pro-inflammatory role and is increased in both CD and UC [50][69][70].

Surprisingly, it was shown that IL-22 has a protective role in IBDs, as it attenuates the intestinal inflammation, inducing the production of a mucine membrane by goblet cells [69-71]. Administration of anti-IL-22 antibodies and IL-22 knockout mice has shown delayed healing of colonic injuries [72], while administration of IL-22 has led to a more rapid recovery in Th2-mediated colitis [70]. This makes IL-22 a promising future target for therapy.

Gene mutations involved in encoding IL-22 and the IL-10R2 subunit of the IL-22R complex have been found to be associated with IBD [73][74]. Another recent paper showed that IL23R genotypes affect IL-22 serum concentrations, linking genetic CD susceptibility to Th17 function [69].

\section{CONCLUSIONS}

Cytokines have an important role in the pathogenesis of IBDs. The identification of new cytokines, as well as the changing of the pathogenesis paradigms in IBDs has been done on animal tests and clinical studies. Thus, there is promising evidence basis for future therapy research based on cytokines and anti-cytokine antibodies.

\section{Non-Standard Abbreviations:}

CD - Crohn's disease, UC - ulcerative colitis, IFN interferon, IL - interleukin, NKT - natural killer T cell, TNF tumor necrosis factor, DC - dendrite cells, Treg - regulatory 
$\mathrm{T}$ cells, Th $-\mathrm{T}$ helper cells, TGF- $\beta$ - transforming growth factor- $\beta$; TL1A - TNF-like 1A, APC - antigen presenting cell, STNF-RI - TNF receptor type I, STNF-RII - TNF receptor type II, iNOS - inducible nitric oxide synthase, VEGF vascular endothelial growth factor, DR3 - death domaincontaining receptor 3 .

Bolile inflamatorii intestinale sunt afecțiuni cronice, caracterizate prin perioade de activitate şi perioade de remisiune. Inflamația este cel mai frecvent tip de răspuns al corpului uman ca mecanism de apărare împotriva agresorilor din mediu. Frecvența şi gradul de inflamație depinde de aria țesutului afectat. Tractul gastrointestinal este, de departe, cel mai susceptibil țesut la răspuns inflamator datorită expunerii constante la diverşi factori antigenici, mutagenici sau toxici.

În bolile inflamatorii intestinale există o pierdere a toleranței imune la flora intestinală care este mediată de diverse substanțe, inclusiv citokinele. Citokinele reprezintă un semnal cheie în răspunsul imun intestinal. Celulele dendritice activate şi macrofagele secretă citokine care intervin activ in reglarea inflamației, atât în boala Crohn cât şi în colita ulcerativă. După secreția lor de către celulele prezentatoare de antigen, citokinele se activează şi diferențiază celulele $T$, activând răspunsul imun dobândit.

Citokinele au un rol important în patogeneza bolilor inflamatorii intestinale. Identificarea unor citokine noi precum şi schimbarea modelelor de patogeneză a bolilor inflamatorii intestinale a fost făcută cu ajutorul testelor pe animale şi a studiilor clinice. Există dovezi promițătoare pentru cercetarea în viitor a unei terapii bazate pe citokine şi anticorpi anti-citokine.

Corresponding author: Prof. Dr. Carmen Fierbințeanu Braticevici,

UMF "Carol Davila"

E-mail: cfierbinteanu@yahoo.com

The authors declare no conflict of interest.

\section{REFERENCES}

1. FIOCCHI C. Intestinal inflammation: a complex interplay of immune and nonimmune cell interactions. The American journal of physiology. 1997; 273(4 Pt 1):G769-75.

2. FIOCCHI C. Immunity and inflammation: separate or unified? In: MacDermott RP, editor. Clinical Immunology in Gastroenterology and Hepatology: from Bench to Bedside. New Orleans: American Gastroenterological Association; $1994 ; 182-8$.

3. BRANDTZAEG P, HALSTENSEN TS, KETT K, KRAJCI P, KVALE D, ROGNUM TO, et al. Immunobiology and immunopathology of human gut mucosa: humoral immunity and intraepithelial lymphocytes. Gastroenterology. 1989; 97(6):1562-84.

4. GRISHAM MB, YAMADA T. Neutrophils, nitrogen oxides, and inflammatory bowel disease. Annals of the New York Academy of Sciences. 1992; 664:103-15.

5. FIOCCHI CB, DG. KATZ, JA. Cytokine production in the human gastrointestinal tract during inflammation. Current Opinion in Gastroenterology. 1994; 10(6):639-44.

6. RAGHOW R. The role of extracellular matrix in postinflammatory wound healing and fibrosis. FASEB journal: official publication of the Federation of American Societies for Experimental Biology. 1994; 8(11):823-31.

7. SHIMIZU Y, SHAW S. Lymphocyte interactions with extracellular matrix. FASEB journal: official publication of the Federation of American Societies for Experimental Biology. 1991; 5(9):2292-9.

8. LEON F, SMYTHIES LE, SMITH PD, KELSALL BL. Involvement of dendritic cells in the pathogenesis of inflammatory bowel disease. Advances in experimental medicine and biology. 2006; 579:117-32.

9. SANCHEZ-MUNOZ F, DOMINGUEZ-LOPEZ A, YAMAMOTO-FURUSHO JK. Role of cytokines in inflammatory bowel disease. World journal of gastroenterology : WJG. 2008; 14(27):4280-8.

10. XAVIER RJ, PODOLSKY DK. Unravelling the pathogenesis of inflammatory bowel disease. Nature. 2007; 448(7152):427-34.

11. INCE MN, ELLIOTT DE. Immunologic and molecular mechanisms in inflammatory bowel disease. The Surgical clinics of North America. 2007; 87(3):681-96.

12. BREESE E, BRAEGGER CP, CORRIGAN CJ, WALKER-SMITH JA, MACDONALD TT. Interleukin-2- and interferongamma-secreting T cells in normal and diseased human intestinal mucosa. Immunology. 1993; 78(1):127-31. 
13. FUSS IJ, NEURATH M, BOIRIVANT M, KLEIN JS, DE LA MOTTE C, STRONG SA, et al. Disparate CD4+ lamina propria (LP) lymphokine secretion profiles in inflammatory bowel disease. Crohn's disease LP cells manifest increased secretion of IFN-gamma, whereas ulcerative colitis LP cells manifest increased secretion of IL-5. Journal of immunology. 1996; 157(3):1261-70.

14. STROBER W, FUSS IJ. Proinflammatory cytokines in the pathogenesis of inflammatory bowel diseases. Gastroenterology. 2011; 140(6):1756-67.

15. BAUMANN H, GAULDIE J. The acute phase response. Immunology today. 1994; 15(2):74-80.

16. BEGUE B, WAJANT H, BAMBOU JC, DUBUQUOY L, SIEGMUND D, BEAULIEU JF, et al. Implication of TNF-related apoptosis-inducing ligand in inflammatory intestinal epithelial lesions. Gastroenterology. 2006;130(7):1962-74.

17. STUCCHI A, REED K, O'BRIEN M, CERDA S, ANDREWS C, GOWER A, et al. A new transcription factor that regulates $T N F$-alpha gene expression, LITAF, is increased in intestinal tissues from patients with CD and UC. Inflammatory bowel diseases. 2006; 12(7):581-7.

18. REIMUND JM, WITTERSHEIM C, DUMONT S, MULLER CD, BAUMANN R, POINDRON P, et al. Mucosal inflammatory cytokine production by intestinal biopsies in patients with ulcerative colitis and Crohn's disease. Journal of clinical immunology. 1996; 16(3):144-50.

19. YAMAMOTO-FURUSHO JK. Innovative therapeutics for inflammatory bowel disease. World journal of gastroenterology: WJG. 2007; 13(13):1893-6.

20. SPOETTL T, HAUSMANN M, KLEBL F, DIRMEIER A, KLUMP B, HOFFMANN J, et al. Serum soluble TNF receptor I and II levels correlate with disease activity in IBD patients. Inflammatory bowel diseases. 2007; 13(6):727-32.

21. MIZOGUCHI E, HACHIYA Y, KAWADA M, NAGATANI K, OGAWA A, SUGIMOTO K, et al. TNF receptor type I-dependent activation of innate responses to reduce intestinal damage-associated mortality. Gastroenterology. 2008; 134(2):470-80.

22. BAMIAS G, MARTIN C, 3RD, MARINI M, HOANG S, MISHINA M, ROSS WG, et al. Expression, localization, and functional activity of TL1A, a novel Th1-polarizing cytokine in inflammatory bowel disease. Journal of immunology. 2003; 171(9):4868-74.

23. PREHN JL, MEHDIZADEH S, LANDERS CJ, LUO X, CHA SC, WEI P, et al. Potential role for TL1A, the new TNF-family member and potent costimulator of IFN-gamma, in mucosal inflammation. Clinical immunology. 2004;112(1):66-77.

24. KAMADA N, HISAMATSU T, HONDA H, KOBAYASHI T, CHINEN H, TAKAYAMA T, et al. TL1A produced by lamina propria macrophages induces Th1 and Th17 immune responses in cooperation with IL-23 in patients with Crohn's disease. Inflammatory bowel diseases. 2010; 16(4):568-75.

25. PREHN JL, THOMAS LS, LANDERS CJ, YU QT, MICHELSEN KS, TARGAN SR. The T cell costimulator TL1A is induced by FcgammaR signaling in human monocytes and dendritic cells. Journal of immunology. 2007; 178(7):4033-8.

26. MICHELSEN KS, THOMAS LS, TAYLOR KD, YU QT, MEI L, LANDERS CJ, et al. IBD-associated TL1A gene (TNFSF15) haplotypes determine increased expression of TL1A protein. PloS one. 2009; 4(3):e4719.

27. DINARELLO CA. The IL-1 family and inflammatory diseases. Clinical and experimental rheumatology. $2002 ; 20$ (5 Suppl 27): S1-13.

28. ASHWOOD P, HARVEY R, VERJEE T, WOLSTENCROFT R, THOMPSON RP, POWELL JJ. Functional interactions between mucosal IL-1, IL-ra and TGF-beta 1 in ulcerative colitis. Inflammation research : official journal of the European Histamine Research Society [et a.l]. 2004; 53(2):53-9.

29. MITSUYAMA K, TOYONAGA A, SASAKI E, ISHIDA O, IKEDA H, TSURUTA O, et al. Soluble interleukin-6 receptors in inflammatory bowel disease: relation to circulating interleukin-6. Gut. 1995; 36(1):45-9.

30. REINISCH W, GASCHE C, TILLINGER W, WYATT J, LICHTENBERGER C, WILLHEIM M, et al. Clinical relevance of serum interleukin-6 in Crohn's disease: single point measurements, therapy monitoring, and prediction of clinical relapse. The American journal of gastroenterology. 1999; 94(8):2156-64.

31. SUZUKI A, HANADA T, MITSUYAMA K, YOSHIDA T, KAMIZONO S, HOSHINO T, et al. CIS3/SOCS3/SSI3 plays a negative regulatory role in STAT3 activation and intestinal inflammation. The Journal of experimental medicine. 2001; 193(4):471-81.

32. VAN KEMSEKE C, BELAICHE J, LOUIS E. Frequently relapsing Crohn's disease is characterized by persistent elevation in interleukin-6 and soluble interleukin-2 receptor serum levels during remission. International journal of colorectal disease. 2000; 15(4):206-10.

33. ATREYA R, MUDTER J, FINOTTO S, MULLBERG J, JOSTOCK T, WIRTZ S, et al. Blockade of interleukin 6 trans signaling suppresses $T$-cell resistance against apoptosis in chronic intestinal inflammation: evidence in Crohn disease and experimental colitis in vivo. Nature medicine. 2000; 6(5):583-8.

34. MUDTER J, NEURATH MF. Apoptosis of T cells and the control of inflammatory bowel disease: therapeutic implications. Gut. 2007; 56(2):293-303.

35. KALLEN KJ. The role of transsignalling via the agonistic soluble IL-6 receptor in human diseases. Biochimica et biophysica acta. $2002 ; 1592(3): 323-43$.

36. YAMAMOTO M, YOSHIZAKI K, KISHIMOTO T, ITO H. IL-6 is required for the development of Th1 cell-mediated murine colitis. Journal of immunology. 2000; 164(9):4878-82.

37. CAREY R, JURICKOVA I, BALLARD E, BONKOWSKI E, HAN X, XU H, et al. Activation of an IL-6:STAT3-dependent transcriptome in pediatric-onset inflammatory bowel disease. Inflammatory bowel diseases. 2008; 14(4):446-57.

38. LEBEL-BINAY S, BERGER A, ZINZINDOHOUE F, CUGNENC P, THIOUNN N, FRIDMAN WH, et al. Interleukin-18: biological properties and clinical implications. European cytokine network. 2000; 11(1):15-26.

39. LEACH ST, MESSINA I, LEMBERG DA, NOVICK D, RUBENSTEIN M, DAY AS. Local and systemic interleukin-18 and interleukin-18-binding protein in children with inflammatory bowel disease. Inflammatory bowel diseases. 2008; 14(1):68-74. 
40. PIZARRO TT, MICHIE MH, BENTZ M, WORARATANADHARM J, SMITH MF, JR., FOLEY E, et al. IL-18, a novel immunoregulatory cytokine, is up-regulated in Crohn's disease: expression and localization in intestinal mucosal cells. Journal of immunology. 1999; 162(11):6829-35.

41. OKAMURA H, KASHIWAMURA S, TSUTSUI H, YOSHIMOTO T, NAKANISHI K. Regulation of interferon-gamma production by IL-12 and IL-18. Current opinion in immunology. 1998; 10(3):259-64.

42. MICALLEF MJ, TANIMOTO T, KOHNO K, IKEGAMI H, KURIMOTO M. Interleukin 18 induces a synergistic enhancement of interferon gamma production in mixed murine spleen cell-tumor cell cultures: role of endogenous interleukin 12. Cancer detection and prevention. 2000; 24(3):234-43.

43. MANGAN PR, HARRINGTON LE, O'QUINN DB, HELMS WS, BULLARD DC, ELSON CO, et al. Transforming growth factor-beta induces development of the T(H)17 lineage. Nature. 2006; 441(7090):231-4.

44. PARADOWSKA A, MASLINISKI W, GRZYBOWSKA-KOWALCZYK A, LACKI J. The function of interleukin 17 in the pathogenesis of rheumatoid arthritis. Archivum immunologiae et therapiae experimentalis. 2007; 55(5):329-34.

45. RUDDY MJ, WONG GC, LIU XK, YAMAMOTO H, KASAYAMA S, KIRKWOOD KL, et al. Functional cooperation between interleukin-17 and tumor necrosis factor-alpha is mediated by CCAAT/enhancer-binding protein family members. The Journal of biological chemistry. 2004; 279(4):2559-67.

46. PARK H, LI Z, YANG XO, CHANG SH, NURIEVA R, WANG YH, et al. A distinct lineage of CD4 T cells regulates tissue inflammation by producing interleukin 17. Nature immunology. 2005; 6(11):1133-41.

47. LANGRISH CL, CHEN Y, BLUMENSCHEIN WM, MATTSON J, BASHAM B, SEDGWICK JD, et al. IL-23 drives a pathogenic T cell population that induces autoimmune inflammation. The Journal of experimental medicine. 2005; 201(2):233-40.

48. HONZAWA Y, NAKASE H, SHIOKAWA M, YOSHINO T, IMAEDA H, MATSUURA M, et al. Involvement of interleukin17A-induced expression of heat shock protein 47 in intestinal fibrosis in Crohn's disease. Gut. 2014;63(12):1902-12.

49. KERAMI Z, DUIJVIS NW, VOGELS EW, VAN DOOREN FH, MOERLAND PD, TE VELDE AA. Effect of interleukin-17 on gene expression profile of fibroblasts from Crohn's disease patients. Journal of Crohn's \& colitis. 2014; 8(10):1208-16.

50. JIANG W, SU J, ZHANG X, CHENG X, ZHOU J, SHI R, et al. Elevated levels of Th17 cells and Th17-related cytokines are associated with disease activity in patients with inflammatory bowel disease. Inflammation research : official journal of the European Histamine Research Society [et al]. 2014; 63(11):943-50.

51. FUJINO S, ANDOH A, BAMBA S, OGAWA A, HATA K, ARAKI Y, et al. Increased expression of interleukin 17 in inflammatory bowel disease. Gut. 2003; 52(1):65-70.

52. TRINCHIERI G. Interleukin-12 and the regulation of innate resistance and adaptive immunity. Nature reviews Immunology. 2003; 3(2):133-46.

53. IIJIMA H, TAKAHASHI I, KISHI D, KIM JK, KAWANO S, HORI M, et al. Alteration of interleukin 4 production results in the inhibition of $T$ helper type 2 cell-dominated inflammatory bowel disease in $T$ cell receptor alpha chain-deficient mice. The Journal of experimental medicine. 1999; 190(5):607-15.

54. GRIGA T, HEBLER U, VOIGT E, TROMM A, MAY B. Interleukin-4 inhibits the increased production of vascular endothelial growth factor by peripheral blood mononuclear cells in patients with inflammatory bowel disease. Hepato-gastroenterology. 2000; 47(36):1604-7.

55. KUHN R, LOHLER J, RENNICK D, RAJEWSKY K, MULLER W. Interleukin-10-deficient mice develop chronic enterocolitis. Cell. 1993; 75(2):263-74.

56. RENNICK DM, FORT MM. Lessons from genetically engineered animal models. XII. IL-10-deficient (IL-10(-/-) mice and intestinal inflammation. American journal of physiology Gastrointestinal and liver physiology. 2000; 278(6):G829-33.

57. MIZOGUCHI A, BHAN AK. A case for regulatory B cells. Journal of immunology. 2006; 176(2):705-10.

58. SATTLER S, LING GS, XU D, HUSSAARTS L, ROMAINE A, ZHAO H, et al. IL-10-producing regulatory B cells induced by IL-33 (Breg(IL-33)) effectively attenuate mucosal inflammatory responses in the gut. Journal of autoimmunity. 2014; 50:107-22.

59. MAREK A, BRODZICKI J, LIBEREK A, KORZON M. TGF-beta (transforming growth factor-beta) in chronic inflammatory conditions - a new diagnostic and prognostic marker? Medical science monitor : international medical journal of experimental and clinical research. 2002; 8(7):RA145-51.

60. KANAZAWA S, TSUNODA T, ONUMA E, MAJIMA T, KAGIYAMA M, KIKUCHI K. VEGF, basic-FGF, and TGF-beta in Crohn's disease and ulcerative colitis: a novel mechanism of chronic intestinal inflammation. The American journal of gastroenterology. 2001; 96(3):822-8.

61. LAWRANCE IC, MAXWELL L, DOE W. Inflammation location, but not type, determines the increase in TGF-betal and IGF-1 expression and collagen deposition in IBD intestine. Inflammatory bowel diseases. 2001; 7(1):16-26.

62. FINA D, CARUSO R, PALLONE F, MONTELEONE G. Interleukin-21 (IL-21) controls inflammatory pathways in the gut. Endocrine, metabolic \& immune disorders drug targets. 2007; 7(4):288-91.

63. FANTINI MC, MONTELEONE G, MACDONALD TT. New players in the cytokine orchestra of inflammatory bowel disease. Inflammatory bowel diseases. 2007; 13(11):1419-23.

64. DE RHAM C, FERRARI-LACRAZ S, JENDLY S, SCHNEITER G, DAYER JM, VILLARD J. The proinflammatory cytokines $I L-2, I L-15$ and $I L-21$ modulate the repertoire of mature human natural killer cell receptors. Arthritis research \& therapy. 2007; 9(6):R125.

65. CHEN Z, LAURENCE A, O'SHEA JJ. Signal transduction pathways and transcriptional regulation in the control of Th17 differentiation. Seminars in immunology. 2007; 19(6):400-8.

66. MONTELEONE G, MONTELEONE I, FINA D, VAVASSORI P, DEL VECCHIO BLANCO G, CARUSO R, ET AL. Interleukin-21 enhances T-helper cell type I signaling and interferon-gamma production in Crohn's disease. Gastroenterology. 2005; 128(3):687-94.

67. YESTE A, MASCANFRONI ID, NADEAU M, BURNS EJ, TUKPAH AM, SANTIAGO A, et al. IL-21 induces IL-22 production in CD4+ T cells. Nature communications. 2014; 5:3753. 
68. ANDOH A, ZHANG Z, INATOMI O, FUJINO S, DEGUCHI Y, ARAKI Y, et al. Interleukin-22, a member of the IL-10 subfamily, induces inflammatory responses in colonic subepithelial myofibroblasts. Gastroenterology. 2005; 129(3):969-84.

69. SCHMECHEL S, KONRAD A, DIEGELMANN J, GLAS J, WETZKE M, PASCHOS E, et al. Linking genetic susceptibility to Crohn's disease with Th17 cell function: IL-22 serum levels are increased in Crohn's disease and correlate with disease activity and IL23R genotype status. Inflammatory bowel diseases. 2008; 14(2):204-12.

70. SUGIMOTO K, OGAWA A, MIZOGUCHI E, SHIMOMURA Y, ANDOH A, BHAN AK, et al. IL-22 ameliorates intestinal inflammation in a mouse model of ulcerative colitis. The Journal of clinical investigation. 2008; 118(2):534-44.

71. LI LJ, GONG C, ZHAO MH, FENG BS. Role of interleukin-22 in inflammatory bowel disease. World journal of gastroenterology : WJG. 2014; 20(48):18177-88.

72. ZINDL CL, LAI JF, LEE YK, MAYNARD CL, HARBOUR SN, OUYANG W, et al. IL-22-producing neutrophils contribute to antimicrobial defense and restitution of colonic epithelial integrity during colitis. Proceedings of the National Academy of Sciences of the United States of America. 2013; 110(31):12768-73.

73. FLOSS DM, MROTZEK S, KLOCKER T, SCHRODER J, GROTZINGER J, ROSE-JOHN S, et al. Identification of canonical tyrosine-dependent and non-canonical tyrosine-independent STAT3 activation sites in the intracellular domain of the interleukin 23 receptor. The Journal of biological chemistry. 2013; 288(27):19386-400.

74. KRYCZEK I, LIN Y, NAGARSHETH N, PENG D, ZHAO L, ZHAO E, et al. IL-22(+)CD4(+) T cells promote colorectal cancer stemness via STAT3 transcription factor activation and induction of the methyltransferase DOTIL. Immunity. 2014; 40(5):772-84. 